\title{
Distribución de genes de resistencia a arsénico en bacterias aisladas de sedimentos con concentraciones variables del metaloide
}

\section{Distribution of arsenic-resistant genes in bacteria from sediments with different concentrations of arsenic}

\author{
Carolina Mellado ${ }^{1}$, Victor Campos ${ }^{1,2} \&$ María A. Mondaca ${ }^{1 *}$ \\ ${ }^{1}$ Departamento. de Microbiología, Facultad de Ciencias Biológicas, Universidad de Concepción, Casilla 160-C. Concepción, \\ Chile. \\ ${ }^{2}$ Centro de Ciencias Ambientales EULA-Chile, Universidad de Concepción, Casilla 160-C, Concepción, Chile. \\ *E-mail: mmondaca@udec.cl
}

\begin{abstract}
RESUMEN
El arsénico es un elemento tóxico, ampliamente distribuido en ambientes terrestres y acuáticos. La biotransformación bacteriana juega un importante rol en el ciclo biogeoquímico de este metaloide, interviniendo en la movilidad, distribución y biodisponibilidad de las distintas especies de arsénico en el ambiente. El objetivo de este trabajo fue relacionar la presencia de los genes ars CBA en bacterias aisladas desde zonas con distintas concentraciones de arsénico presente en los sedimentos de diferentes sectores del río Camarones (Región Arica y Parinacota). Se aislaron 34 cepas bacterianas arseniato-resistentes, a las cuales se les determinó los niveles de tolerancia a $\mathrm{As}(\mathrm{V})$ y $\mathrm{As}(\mathrm{III})$; la actividad reductora de arseniato, mediante la técnica semi-cuantitativa con $\mathrm{AgNO}_{3}$ y la detección de genes ars, por PCR. El 100\% de las cepas fueron tolerantes a As(V) y As(III) y presentaron el gen $\operatorname{ars} C$, siendo capaces de reducir As(V) a As(III). El gen arsB se detectó en el $86 \%$ de las cepas presentes en los sedimentos con mayor concentración de arsénico (Illapata) y $71 \%$ el ars $A$; mientras que en las cepas provenientes de sedimentos con menores concentraciones, los genes ars $B$ y ars $A$ se detectaron en el $80 \%$ y $40 \%$, para las cepas provenientes de Esquiña y el 50\% y 25\% para las de Desembocadura. De acuerdo a los resultados se puede concluir que, la frecuencia de detección de genes $\operatorname{ars} C B A$ está directamente relacionada con la concentración de arsénico presente en los diferentes sedimentos analizados.
\end{abstract}

Palabras claves: arseniato, bacterias arseniato-reductoras, genes $\operatorname{ars} C B A$.

\begin{abstract}
Arsenic is a toxic element, widely distributed in terrestrial and aquatic environments. Microbial biotransformation processes play a key role in the biogeochemical cycle of arsenic and can be involved in the mobility, distribution and bioavailability of the arsenic species in the environment. The objective of this study was to relate the presence of the $\operatorname{ars} C B A$ genes of arsenate-reducing bacteria isolated from sediments coming from different sectors of the Camarones River (Arica $y$ Parinacota region, Chile) showing different arsenic concentrations. We isolated 34 arsenate-resistant bacteria for which tolerance levels to As (III) and As (V) were determined as the arsenate reducing activity by semi-quantitative technique with AgNO3 and the presence of the ars genes, by PCR. All strains were tolerant to As (III) and As (V) and showed the $\operatorname{ars} C$ gene, which is capable of reducing As (V) to As (III). The arsB gene was detected in $86 \%$ of the strains present in the sediments with higher concentrations of arsenic (Illapata sector) while and the the ars $A$ gene was detected in $71 \%$. The strains isolated from sediments with lower arsenic concentrations showed the presence of the $\operatorname{ars} B$ and $\operatorname{ars} A$ genes in the $80 \%$ and $40 \%$ of isolates from the "Esquiña" sector and in $50 \%$ and $25 \%$ of isolates from the "Desembocadura" sector. According to this, we can conclude that detection frequency of ars genes of the strains under study increase in those river sections having higher arsenic concentrations, but the resistance to arsenic does not increase concomitantly.
\end{abstract}

KEYwords: arsenate, arsenate-reducing bacteria, $\operatorname{ars} C B A$ genes. 


\section{INTRODUCCIÓN}

El arsénico es un metaloide tóxico y ampliamente distribuido en ambientes terrestres y acuáticos. En éstos, predominan las formas inorgánicas, principalmente como arsenito [As(III)] y arseniato $[\mathrm{As}(\mathrm{V})]$, siendo la primera la especie más tóxica y móvil. La transformación bacteriana juega un importante rol en el ciclo biogeoquímico del arsénico, interviniendo en la movilidad, distribución y biodisponibilidad de las distintas especies de arsénico en el ambiente (Mukhopadhyay et al. 2002). En lugares contaminados con el metaloide, se han aislado microorganismos que presentan diversos mecanismos de resistencia que les permite tolerar las concentraciones de arsénico que mantiene su hábitat. Los principales mecanismos de resistencia bacteriana, se encuentran asociados a determinantes genéticos, que les otorgan la capacidad de realizar transformaciones de oxidación y/o reducción del metaloide (Silver \& Phung 2005). En el caso de las bacterias arseniato-reductoras Gram-negativas, el sistema más estudiado corresponde al operón ars el cual puede ser de origen plasmidial o cromosomal y funcionar bajo condiciones aeróbicas o anaeróbicas (Silver \& Phung 2005). En el plásmido R733, de E. coli, se han encontrado cinco genes: $\operatorname{ars} A, \operatorname{ars} B, \operatorname{ars} C, \operatorname{ars} D$ y $\operatorname{ars} R$, mientras que a nivel cromosomal solo tres: $\operatorname{ars} B$, ars $C$, y ars $R$. El gen $\operatorname{ars} C$, codifica para una proteína encargada de mediar la reducción de arseniato a arsenito en el citoplasma, para luego ser eliminado hacia el exterior de la célula a través de una bomba específica de eflujo (ATPasa) asociada a una subunidad integral en la membrana, formando el complejo $\operatorname{ars} A B$, codificado por los genes ars $A$ y ars $B$, respectivamente. Los genes $\operatorname{ars} D$ y ars $R$ codifican para proteínas responsables de la regulación del operón (Rosen 2002).

La contaminación por arsénico en el norte de Chile es principalmente de origen geológico y los niveles de éste en el río Camarones (XV región) supera 100 veces el límite permitido por la Organización Mundial de la Salud, EPA y la Norma Chilena 409, para el consumo de agua potable (Yañez et al. 2005). Estudios realizados por Escalante et al. (2009) demuestran que los sedimentos del río Camarones poseen una actividad biológica responsable de la transformación de arsénico mediante bacterias reductoras del metaloide. De acuerdo a ello, el objetivo de este trabajo fue relacionar la frecuencia de aparición de los genes ars $C B A$ con distintas concentraciones de arsénico presente en los sedimentos de diferentes sectores del río Camarones (Región Arica y Parinacota, Chile).

\section{MATERIALES Y MÉTODOS}

Sitio De MUESTREO

Las cepas bacterianas fueron aisladas desde sedimentos de los sectores Illapata, Esquiña y Desembocadura del río Camarones y del río Lauca (Region Arica y Parinacota, Chile). Estos sectores presentan 1,3; 1; 0,5 y 0,09 mg arsénico $\mathrm{L}^{-1}$ total, respectivamente.

\section{DETERMINACIÓN DE NIVELES DE TOLERANCIA}

Los niveles de tolerancia a arsénico se determinaron mediante la técnica de dilución seriada en placa (NCCL 1992). Se utilizó agar Luria (Difco), al cual se añadió concentraciones líquidas variables de arseniato y arsenito de sodio, entre 1 y $100 \mathrm{mM}$ y 1 y $50 \mathrm{mM}$, respectivamente (La concentración aumenta el doble para cada concentración de la serie; Escalante et al. 2009). Cada una de las placas fue inoculada con diluciones apropiadas de cultivos bacterianos de $24 \mathrm{~h}$ de incubación. Como control, se inocularon placas con agar Luria (Difco) sin arsénico. Las placas se incubaron a $25^{\circ} \mathrm{C}$ durante 24 a 48 $\mathrm{h}$ y se observó la presencia de desarrollo bacteriano (Muller et al. 2003). Las cepas bacterianas fueron seleccionadas de acuerdo a los descrito por Rokbani et al. (2007)

\section{ACTIVIDAD REDUCTORA DE ARSENIATO}

Las cepas bacterianas se cultivaron en caldo Luria y se incubaron a $25^{\circ} \mathrm{C}$ por $24-48 \mathrm{~h}$. Cuando el cultivo alcanzó una densidad óptica entre $0.4-0.6_{\text {abs }}$ a $600 \mathrm{~nm}$, se tomó $1 \mathrm{~mL}$ del cultivo, se traspasó a un tubo Eppendorf y se centrifugó a $1500 \mathrm{rpm}$ durante $10 \mathrm{~min}$. El pellet obtenido fue lavado dos veces con medio mínimo descrito por Macur et al. (2004), adicionado con lactato, para luego resuspenderlo en $1 \mathrm{~mL}$ del mismo medio. Cien microlitros de la suspensión celular se agregó a un tubo Eppendorf con $400 \mu l$ de medio mínimo $(\mathrm{pH} 7.0$ ) adicionado con $\mathrm{As}(\mathrm{V}) 2 \mathrm{mM}$. Luego, se incubaron a $25^{\circ} \mathrm{C}$ durante $24-48 \mathrm{~h}$. Posteriormente se agregaron $100 \mu \mathrm{l} \mathrm{de}$ $\mathrm{AgNO}_{3}, 0.1 \mathrm{M}$. Los resultados obtenidos fueron comparados con un estándar descrito por Simeonova et al. (2004).

\section{DETECCIÓN DE LOS GENES ars $A B C$, MEDIANTE PCR}

Las cepas bacterianas fueron cultivadas en caldo Luria por $24 \mathrm{~h}$ a $25^{\circ} \mathrm{C}$. El ADN total se obtuvo a partir de un cultivo de cada una de las cepas en caldo Luria de 18 a $24 \mathrm{~h}$ de incubación a $25^{\circ} \mathrm{C}$, utilizando el kit Instagene ${ }^{\mathrm{TM}}$ Matrix (BioRad), de acuerdo a las instrucciones de los proveedores. La presencia de los genes ars $A B C$, se detectó mediante PCR utilizando como partidores los mencionados en la Tabla 1. El análisis de PCR se realizó en un termociclador Px2 Thermal cycler (Thermo, electron Corporation). La mezcla de reacción estuvo compuesta por buffer Tris- $\mathrm{HCl}$ (pH 8.3) $10 \mathrm{mM}, 50 \mathrm{mM} \mathrm{KCl}, 2.0 \mathrm{Mm} \mathrm{MgCl} 2,200 \mathrm{nM}$ de cada partidor, $0.625 \mathrm{U}$ de Taq polimerasa (Roche) por $25 \mu \mathrm{l}$, y $50 \mathrm{ng}$ ADN (templado). Se utilizó un protocolo de amplificación diferente para cada set de primer, como se muestra a continuación: Paso inicial de denaturación $\left(94^{\circ} \mathrm{C}\right.$ por $3 \mathrm{~min}$ ) seguido por 30 a 35 ciclos de $94^{\circ} \mathrm{C}$ por $30 \mathrm{~s}, 58^{\circ} \mathrm{C}$ por $30 \mathrm{~s} \mathrm{y} 72^{\circ} \mathrm{C}$ por $30 \mathrm{~s}(\operatorname{ars} A)$ o 30 a 35 ciclos de $94^{\circ} \mathrm{C}$ por $30 \mathrm{~s}, 59^{\circ} \mathrm{C}$ por $30 \mathrm{~s}$, y $72^{\circ} \mathrm{C}$ por $30 \mathrm{~s}(\operatorname{ars} B$ 
y $\operatorname{ars} C)$ y 30 a 35 ciclos de $94^{\circ} \mathrm{C}$ por $30 \mathrm{~s}, 42^{\circ} \mathrm{C}$ por $30 \mathrm{~s}$ y $72^{\circ} \mathrm{C}$ por $30 \mathrm{~s}\left(\operatorname{ars} C^{\prime}\right)$. La extensión final se realizó por $7 \mathrm{~min}$ a $72^{\circ} \mathrm{C}$. Enterobacter aerogenes fue utilizada como control positivo (Escalante et al. 2009). Agua DEPC con grado biología molecular (MoBio, Inc) fue utilizada como control negativo. Los productos de amplificación (alícuotas de 5- a 10- $\mu$ l) fueron separados mediante electroforesis en gel de agarosa al $1,5 \%(0,5 \mu \mathrm{g}$ de bromuro de etidio por $\mathrm{mL}$ ). Las bandas fueron visualizadas en un transiluminador UV (Saltikov \& Olson 2002).

\section{AnÁLISIS ESTAdísticos}

Los resultados de la detección de genes ars $A B C$, se sometieron a análisis estadísticos de escalamiento multidimensional no paramétrico. Para comparar las diferentes zonas de muestreos, una matriz binaria fue construida en base al número de bacterias con genes ars $A B C$, para cada sector de muestreo. Los analisis de clusters y MDS fueron realizados mediante Primer 5 software package (Clarke \& Gorley 2001).

\section{RESULTADOS}

\section{CARACTERIZACIÓN DE LAS CEPAS BACTERIANAS}

Las cepas bacterianas pertenecientes al río Camarones, presentaron niveles de tolerancia entre $10 \mathrm{y}>20 \mathrm{mM}$, para arsenito $\mathrm{y}>100 \mathrm{mM}$, para arseniato, mientras que las cepas aisladas del río Lauca mostraron niveles de tolerancia entre 8-10 $\mathrm{mM}$, para arsenito y entre $50-100 \mathrm{mM}$, para arseniato (Tabla 2).

Al estudiar la capacidad reductora de las cepas bacterianas ensayadas, mediante la técnica semi-cuantitativa con $\mathrm{AgNO}_{3}$, se encontró que el $42,8 \%$ de las bacterias aisladas desde sedimentos del sector Illapata fueron capaces de reducir entre $25-50 \%$ el arseniato del medio, mientras que el $57 \%$ de ellas biotransformó a arsenito entre 75 y $90 \%$ del arseniato total. El $70 \%$ de las cepas provenientes del sector Esquiña fueron capaces de reducir entre $25-50 \%$ y el $30 \%$ redujo entre $75-70 \%$ del arseniato del medio a arsenito. En las cepas pertenecientes al sector Desembocadura, esta relación corresponde a un $85 \%$ de las cepas con capacidad de reducir entre $75-90 \%$ y un $25 \%$ lo redujo entre $25-50 \%$. Mientras que el $100 \%$ de las bacterias provenientes del río Lauca solo fueron capaces de reducir hasta un $50 \%$ del arseniato del medio (Tablas 2 y 3 ).

\section{Detección de Los Genes ars $A B C$, Mediante PCR}

Los resultados muestran la existencia de cepas bacterianas capaces de tolerar elevados niveles de arsenito y arseniato, motivo por el cual se investigó la presencia de los genes involucrados en la reducción de arseniato a arsenito en el citoplasma y en el eflujo de arsenito al exterior. Al realizar una PCR, utilizado los partidores diseñados para el operón ars de E. coli, se obtuvo un producto de amplificación de $370 \mathrm{pb}$ aproximadamente (Fig. 1), que correspondió al gen $\operatorname{ars} C$, en 22 de las 34 cepas ensayadas, de acuerdo a lo descrito por Saltikov \& Olson (2002). A las cepas arsC negativas se les realizó una nueva PCR, utilizando los partidores diseñados para el operón ars de Pseudomonas aeruginosa y Pseudomonas putida, resultando todas las cepas positivas, con un producto de amplificación de 450 pb. Para la amplificación de los genes ars $A$ y ars $B$ se utilizaron partidores diseñados para el operón ars de $E$. coli, en este ensayo 24 cepas dieron resultados positivos para el gen $\operatorname{ars} B$ (producto de amplificación de $219 \mathrm{pb}$ ) y 13 cepas para el gen arsA (producto de amplificación de $186 \mathrm{pb}$ ) (Tabla 2).

TABLA 1. Partidores utilizados para amplificar los genes arsCBA de las cepas bacterianas en estudio.

TABLE 1. Primers used to amplify ars $C B A$ genes of the bacterial strains studied.

\begin{tabular}{|c|c|c|}
\hline Nombre partidor & Secuencia $\left(5^{\prime}-3^{\prime}\right)$ & Producto $(\mathrm{pb})$ \\
\hline $\operatorname{arsA}-F^{a}$ & ACCCACGCTTAGCAATATCATCGA & \multirow{2}{*}{186} \\
\hline $\operatorname{arsA}-R^{a}$ & TGAAAGTCTTCATATAGGTCT TCC & \\
\hline $\operatorname{arsB}-F^{a}$ & GTGGAATATCGTCTGGAATGCGAC & \multirow{2}{*}{219} \\
\hline $\operatorname{arsB}-\mathrm{R}^{\mathrm{a}}$ & GTGGAATATCGTCTGGAATGCGAC & \\
\hline $\operatorname{arsC}-\mathrm{F}^{\mathrm{a}}$ & TGCGGCACTTCGTGAAACAC & \multirow{2}{*}{370} \\
\hline $\operatorname{arsC}-\mathrm{R}^{\mathrm{a}}$ & AAGTATATCCAGAAC CACTT & \\
\hline $\operatorname{arsCPs}-\mathrm{F}^{\mathrm{b}}$ & AGTCCTGTTCATGTGYAC & \multirow{2}{*}{450} \\
\hline $\operatorname{arsCPs}-\mathrm{R}^{\mathrm{b}}$ & TGGCGTSGAAYGCCG & \\
\hline
\end{tabular}

Partidores diseñados a partir del operón ars de Escherichia coli R773.

${ }^{\mathrm{b}}$ Partidores diseñados a partir del operón ars Pseudomonas aeruginosa/putida. 
TABLA 2. Caracterización de 34 cepas bacterianas aisladas desde los distintos sectores del río Camarones y Lauca.

TABLE 2. Characterization of 34 bacterial strains isolated from different sites of the Camarones and Lauca river.

\begin{tabular}{|c|c|c|c|c|c|}
\hline \multirow{2}{*}{ Sector/Cepa } & \multirow{2}{*}{$\begin{array}{c}\text { Actividad }^{1} \\
\text { Reductora \% }\end{array}$} & \multirow{2}{*}{$\begin{array}{l}\text { Nivel de tolerancia } \\
\text { a } \mathrm{As}(\mathrm{V}) / \mathrm{As}(\mathrm{III}) \mathrm{mM}\end{array}$} & \multicolumn{3}{|c|}{ Genes $^{2}$} \\
\hline & & & $\operatorname{ars} C$ & $\operatorname{ars} B$ & $\operatorname{ars} A$ \\
\hline \multicolumn{6}{|l|}{ Illapata } \\
\hline IA 2 & 90 & $>100 />20$ & + & + & + \\
\hline IA 3 & 75 & $>100 />20$ & + & + & + \\
\hline IA4 & 50 & $>100 />20$ & + & + & + \\
\hline IA5 & 50 & $>100 />20$ & $t^{3}$ & + & - \\
\hline IA7 & 50 & $>100 />20$ & + & + & + \\
\hline IA10 & 25 & $>100 />20$ & + & - & - \\
\hline IA11 & 75 & $>100 / 10$ & + & + & + \\
\hline \multicolumn{6}{|l|}{ Esquiña } \\
\hline IIA1 & 75 & $>100 / 10$ & + & + & + \\
\hline IIA2 & 75 & $>100 />20$ & + & + & + \\
\hline IIA4 & 25 & $>100 / 10$ & + & - & - \\
\hline IIA5 & 50 & $>100 />20$ & $t^{3}$ & + & - \\
\hline IIA6 & 50 & $>100 / 10$ & + & + & - \\
\hline IIA7 & 25 & $>100 / 10$ & $t^{3}$ & - & + \\
\hline IIA8 & 50 & $>100 />20$ & + & + & - \\
\hline IIA9 & 75 & $>100 />20$ & + & + & + \\
\hline IIA11 & 50 & $>100 />20$ & + & + & - \\
\hline IIA12 & 50 & $>100 />20$ & + & + & - \\
\hline \multicolumn{6}{|c|}{ Desembocadura } \\
\hline IIIA1 & 75 & $>100 / 20$ & + & + & + \\
\hline IIIA2 & 50 & $>100 / 20$ & + & - & - \\
\hline IIIA3 & 25 & $>100 / 10$ & + & + & - \\
\hline IIIA6 & 25 & $>100 / 10$ & + & + & - \\
\hline IIIA7 & 25 & $>100 />20$ & $t^{3}$ & - & - \\
\hline IIIA8 & 50 & $>100 />20$ & + & + & + \\
\hline IIIA9 & 25 & $>100 / 20$ & + & - & - \\
\hline IIIA10 & 10 & $>100 / 10$ & $t^{3}$ & - & - \\
\hline \multicolumn{6}{|l|}{ Lauca } \\
\hline LE1 & 10 & $100 / 10$ & $t^{3}$ & - & - \\
\hline LE4 & 25 & $100 / 10$ & + & - & + \\
\hline LE5 & 25 & $100 / 10$ & $+^{3}$ & - & - \\
\hline LE6 & 10 & $100 / 10$ & + & + & - \\
\hline LE7 & 10 & $100 / 10$ & $+^{3}$ & - & - \\
\hline LE8 & 10 & $100 / 10$ & + & + & - \\
\hline LE10 & 25 & $100 / 10$ & $t^{3}$ & + & + \\
\hline LE11 & 10 & $50 / 10$ & $t^{3}$ & + & - \\
\hline LE12 & 10 & $50 / 10$ & $+^{3}$ & - & - \\
\hline
\end{tabular}

Cepas bacterianas As(V)-resistentes. ${ }^{1}$ Análisis semicuantitativo con $\mathrm{AgNO}_{3} ;{ }^{2}$ Detección de genes del operón ars, mediante PCR; +/-: amplicones utilizando partidores diseñados para el operón de $E$. coli; ${ }^{+3}$ :amplicones utilizando partidores diseñados para el operón de Pseudomonas. 
AnÁLISIS ESTADísticos

Para determinar la similitud genética de las cepas bacterianas en estudio, respecto de la presencia de los genes de resistencia a arseniato (operón ars), se utilizó el análisis de Escalamiento Multidimensional no paramétrico (MDS), el cual se basa en el cálculo de coeficientes de similitud/disimilitud entre muestras, en este caso el coeficiente de similitud de Bray-Curtis (Bray \& Curtis 1957). El análisis resulta en un diagrama de puntos, en el que cada punto representa una muestra y la distancia entre ellos, sigue el mismo orden de rango que la similitud de composición de especies entre pares de muestras (Clarke

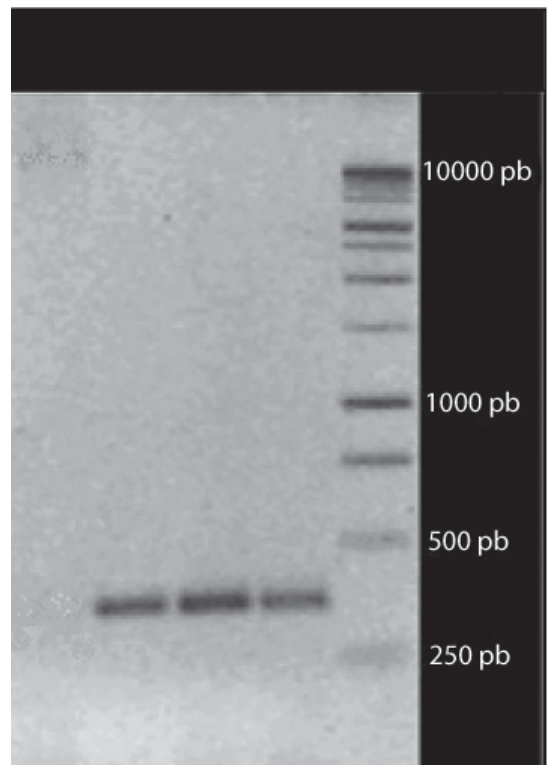

Figura 1. Electroforesis en geles de agarosa desde productos de PCR, usando los partidores arsC. Carril 1: Control negativo, Carril 2: Control Positivo, Carril 3: Cepa IA3, Carril 4: Cepa IIIA1, MP: Macador de peso molecular.

FIGURE 1. Electrophoresis in agarose gel from PCR products using ars C primers. Line 1: Negative control, Line 2: Positive control, Line 3: IA3 strain, Line 4: IIIA1 strain. MP: DNA Ladder.
\& Warwick 1994). De acuerdo a ello, la Figura 2 muestra la presencia de dos grupos, que corresponden a las cepas bacterianas aisladas desde sedimentos del río Camarones (M1, M2, M3) y otro a las provenientes de los sedimentos del río Lauca (M4). Dentro del primer grupo es posible distinguir 3 subgrupos que corresponden a los sectores Illapata, Esquiña y Desembocadura y a su vez, se observa que Illapata y Esquiña, presentan mayor similitud entre las cepas bacterianas que componen la muestra (95\%) que éstas con las obtenidas del sector Desembocadura (80\%).

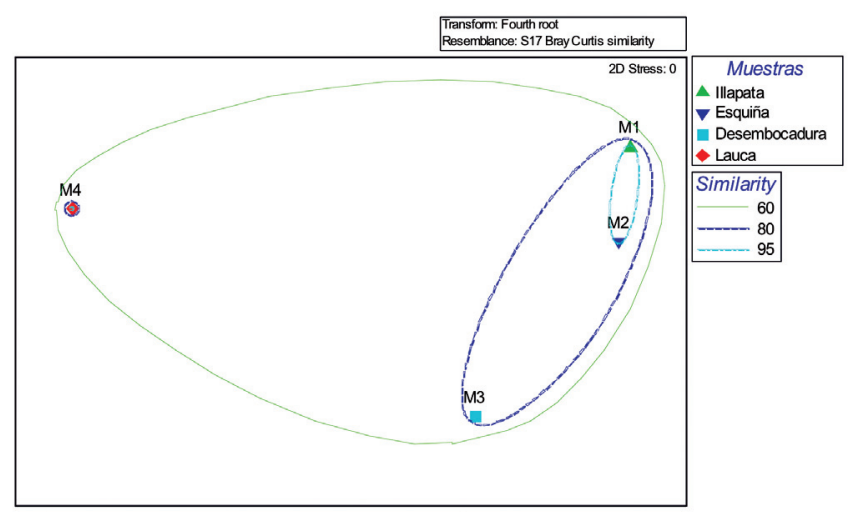

FIGURA 2. Análisis escalamiento multidimensional no paramétrico, basado en la detección de genes $\operatorname{ars} A B C$ en cepas aisladas de tres sectores del río Camarones y del río Lauca. M1: Illapata; M2: Esquiña; M3: Desembocadura; M4: río Lauca.

FIGURE 2. Multidimensional scaling analysis non-parametric, based in the detection of $\operatorname{ars} A B C$ genes from bacterial isolated of three sector of the Camarones river and Lauca river. M1: Illapata; M2: Esquiña; M3: Desembocadura; M4: Lauca river.

TABLA 3. Porcentajes de reducción bacteriana por sectores del río Camarones y Lauca.

TABLE 3. Bacterial reduction rate by sectors of the Camarones and Lauca river.

\begin{tabular}{lcc}
\hline \multirow{2}{*}{ Sector } & \multicolumn{2}{c}{ Reducción de arseniato (\%) } \\
\cline { 2 - 3 } Illapata & $25-50 *$ & $75-90^{* *}$ \\
Esquiña & 42.8 & 57.0 \\
Desembocadura & 70.0 & 30.0 \\
Lauca & 85.0 & 25.0 \\
\end{tabular}

*Porcentaje de cepas bacterianas que son capaces de reducir, *: entre el 25 y $50 \%$ de arseniato del medio **entre el 75 y $90 \%$ del arseniato del medio. 


\section{DISCUSIÓN}

Existen evidencias que indican que los microorganismos presentes en ambientes enriquecidos con arsénico tienen un rol importante en la especiación química del mismo, por esta razón es interesante conocer las estrategias que éstos utilizan para transformar el metaloide y detoxificarlo, como mecanismos de supervivencia.

Los experimentos de medición de los niveles de tolerancia a arsenito y arseniato realizados a las cepas en estudio, arrojaron que las provenientes del río Camarones son capaces de tolerar entre $10-20 \mathrm{mM}$ de arseniato $\mathrm{y}>100$ $\mathrm{mM}$ de arseniato; mientras que las cepas provenientes del río Lauca (sector utilizado como control, por las bajas concentraciones de arsénico detectada) fueron capaces de tolerar entre 8-10 mM de arsenito y entre $50-100 \mathrm{mM}$ de arseniato. De acuerdo al criterio de Rokbani et al. (2007), que clasifican una bacteria como resistente cuando ésta es capaz de crecer en medios con concentraciones $>$ a $7 \mathrm{mM}$ para arsenito y $>20 \mathrm{mM}$ para arseniato, el $100 \%$ de las cepas bacterianas utilizadas en este estudio corresponden a cepas con altos niveles de tolerancia a ambas especies de arsénico. Estudios de Salmassi et al. (2002) sobre cepas bacterianas altamente tolerantes a arseniato, aisladas desde minas de oro contaminadas con arsénico alcanzaron niveles de tolerancia de $100 \mathrm{mM}$. De acuerdo a ello, las cepas bacterianas aisladas desde sedimentos del río Camarones estarían presentando niveles de tolerancia muy similares a los máximos informados en la literatura (Tabla 2). Por otro lado, los resultados demuestran que no existen relación entre la concentración detectada en los sectores de muestreo con los niveles de tolerancia al metaloide, de las cepas bacterinas aisladas, detectando altos niveles de tolerancia $(100 \mathrm{mM})$ en sectores con baja o nula concentración de arsénico. Estos resultados contradice lo mencionado por Jackson et al. (2005), los cuales mencion que los altos niveles de tolerancia de las bacterias aisladas se debe a la presencia de concentraciones significativas de arsénico.

Los ensayos realizados para detectar la capacidad reductora de las cepas en estudio, indicaron que las cepas bacterianas provenientes de sedimentos del río Camarones presentan porcentajes de reducción entre un 25-90\%, para el sector de Illapata; entre un $25-75 \%$ para el sector Esquiña y Desembocadura, mientras las cepas aisladas desde sedimentos del río Lauca arrojaron porcentajes de reducción que varían entre 10-25\%. Indicando que los sectores contaminados con mayores concentraciones de arsénico muestran mayores porcentajes de reducción (Tabla 3). Patel et al. (2007), utilizando la cepa Pseudomonas sp. As-1 (aislada desde electroplacas de efluentes industriales), capaz de tolerar concentraciones de hasta $65 \mathrm{mM}$ de $\mathrm{As}(\mathrm{V})$, demostraron mediante espectroscopía de absorción de rayos
$X$, que ésta cepa puede transformar hasta un $92 \%$ de areniato a arsenito, al adicionar $5 \mathrm{mM}$ de $\mathrm{As}(\mathrm{V})$ al medio de cultivo. Sugiriendo que los cultivos bacterianos fueron capaces de captar e incorporar As(V) al citoplasma, reducirlo a As(III) y expulsarlo de la célula, como mecanismo de detoxificación.

Los enfoques moleculares más frecuentemente utilizados para estudiar comunidades microbianas o estrategias de supervivencia bacteriana, aisladas desde ambientes contaminados con arsénico son la reacción en cadena de la polimerasa (PCR) y sondas genéticas (Wobus et al. 2003). Las ventajas en la utilización de este tipo de métodos incluyen una mejor evaluación de la respuesta de las células bacterias frente a la contaminación ambiental (Saltikov \& Olson 2002).

Al determinar la presencia del gen arsC, utilizando partidores diseñados para el gen ars $C$ de $E$. coli, el $65 \%$ de las cepas en estudio dio resultados positivos. A las cepas ars $C$ negativas, se les realizó una nueva amplificación utilizando los partidores diseñados para el gen en Pseudomonas aeruginosa y Pseudomonas putida, y en este caso, el $35 \%$ restante amplificó positivamente. El gen ars $B$, se detectó en el $71 \%, 80 \%, 50 \%$ y $44 \%$ de las cepas aisladas desde los sedimentos de los sectores Illapata, Esquiña, Desembocadura y río Lauca, respectivamente. Mientras el gen arsA se encontró en el $71 \%, 40 \%, 38 \%$ y $25 \%$ de las cepas aisladas desde los sedimentos de los sectores Illapata, Esquiña, Desembocadura y río Lauca, respectivamente. En cuanto a la aparición de genes $\operatorname{ars} A B$, esta frecuencia es mayor en aquellos sectores donde la contaminación por arsénico mantiene también mayores niveles del metaloide (Illapata $1,3 \mathrm{mg}$ arsénico $\mathrm{L}^{-1}$ y Esquiña, $1 \mathrm{mg}$ arsénico $\left.\mathrm{L}^{-1}\right)$, respecto de las cepas provenientes del sector Desembocadura $(0,5 \mathrm{mg}$ arsénico $\left.\mathrm{L}^{-1}\right)$ o a las pertenecientes al río Lauca $(0,009 \mathrm{mg}$ arsénico $\left.\mathrm{L}^{-1}\right)$. La ausencia de los genes $\operatorname{ars} A B$, puede deberse a que las cepas negativas, presenten el gen, pero que su secuencia sea lo suficientemente diferente a la secuencia de los partidores utilizados y por ende no sean detectables (Saltikov \& Olson, 2002). Por otro lado la ausencia del gen ars $B$, podría explicarse como la presencia del operón ars en un transposón de tipo Tn-21, donde Tuffin et al. (2004) reportaron la aparición de un nuevo operón que carece del gen $\operatorname{ars} B$, pero que sin embargo, es capaz de tolerar elevadas concentraciones de arseniato. Sin embargo, este nuevo modelo, aún no tiene explicación de cómo es bombeado el As(III) al exterior de la célula bacteriana.

Los resultados de la presencia o ausencia de genes ars $A B C$ fueron analizados mediante métodos estadísticos con el objeto de establecer una relación entre las diferentes concentraciones de arsénico correspondientes a los distintos sectores del río Camarones y Lauca y los determinantes 
genéticos que presentaron las cepas aisladas de dichos sedimentos. Esto se confirma con los resultados del análisis por MDS (análisis de escalamiento multidimensional), que mostraron que la frecuencia de los genes $\operatorname{ars} C B A$ de Illapata y Esquiña sería similar, los que a su vez serían diferentes de los detectados en Desembocadura y ambos grupos, estarían distantes de los detectados en el río Lauca. Además, como medida informativa de la fidelidad del modelo, se utiliza el stress, el cual indica que mientras mayor sea la diferencia entre las disparidades y las distancias, mayor será el stress y por lo tanto menos confiable será el modelo. De esta forma su valor mínimo es cero y se considera un modelo bueno desde un valor de stress igual o inferior a 0,025 (Kruskal 1964). En el caso del análisis de ordenamiento de los datos en estudio, este arrojó un valor de stress inferior a 0,025 , demostrando que existe un buen ordenamiento de la matriz de similaridad entre las cepas bacterianas analizadas generando un mapa de interpretación con bajo riesgo de error.

De acuerdo esta investigación, se puede concluir que, si bien la presencia de genes ars en las cepas bacterianas en estudio, es independiente de la concentración de arsénico del medio del que fue aislada, presenta una directa relación con la frecuencia de aparición y con la expresión de los mecanismos de supervivencia frente a la exposición a metaloide.

\section{AGRADECIMIENTOS}

Este trabajo fue financiado por el proyecto FONDECYT $\mathrm{N}^{\circ}$ 1050088 y proyecto DIUC No2008.036.035-1.0.

\section{BIBLIOGRAFÍA}

BRAY, J.R. \& CURTIS, J.T. 1957. An ordination of the upland forest communities of southern Wisconsin. Ecological Monographs 27:325-349.

Clarke, K.R. \& Warwick, R.M. 1994. Similarity-based testing for community pattern: the 2-way layout with no replication. Marine Biology 118:167-176.

Clarke, K. \& Gorley, R. 2001. PRIMER v5: user manual/tutorial, PRIMER-E, Plymouth, UK.

Escalante, G., Campos, V.L., Valenzuela, C., Yañez, J., Zaror, C. \& Mondaca, M.A. 2009. Arsenic Resistant Bacteria Isolated from Arsenic Contaminated River in the Atacama Desert (Chile). Bulletin Environmental Contamination and Toxicology 83:657-661

JaCkson, C., Harrison, K.G. \& Gugas, S.L. 2005. Enumeration and characterization of culturable arsenate resistant bacteria in a large estuary. Systematic and Applied Microbiology 28:727-734

KruSKAL, J.B. 1964. Nonmetric multidimensional scaling: a numerical method. Psychometrika 29: 115-129.

Macur, R.E., Colin, J., Botero, I., Dermott, M.C. \& Inskeep, T.R. 2004. Bacterial populations associated with the oxidation and reduction of arsenic in an unsaturated soil. Environmental Science and Technology 38:101-111.

Mukhopadhyay, R., Rosen, B., Phung L. \& Silver, S. 2002. Microbial arsenic: from geocycles to genes. FEMS Microbiology Reviews 26:311-325.

Muller, D., Lievremont, D., Simeonova, D.D., Hubert, J.C. \& LETT, M.C. 2003. Arsenite oxidase aox genes from a metal resistant beta-proteobacterium. Journal of Bacteriology 185:135-141.

National Committee for Clinical Laboratory. 1992. Standards Performance standards for antimicrobial disk susceptibility tests fourth edition; Approved Standard NCCLS Document M2-A4, Villanora.

Patel, P., Goulhen, F., Boothman, C., Gault, A., Charnock, J., Kalia, K. \& Lloyd, J. 2007. Arsenate detoxification in a Pseudomonas hypertolerant to arsenic. Archives of Microbiology187:171-183.

Rokbani, A., Bauda, P. \& Billard, P. 2007. Diversity of arsenite transporter genes from arsenic-resistant soil bacteria. Research in Microbiology 158(2):128-137.

Rosen, b. 2002. Biochemistry of arsenic detoxification. FEMS Microbiology Letters 529:86-92.

Salmassi, T.M., Venkateswaren, K., Satomi, M., Nealson, K., Newman, D. \& Hering, J. 2002. Oxidation of arsenite by Agrobacterium albertimagni, AOL15, sp. Nov., Isolated from Hotcreek, California. Geomicrobiology Journal 19:53-66.

Saltikov, C.W. \& Olson, B.H. 2002. Homology of Escherichia coli $\mathrm{R} 773 \operatorname{ars} A$, ars $B$, ars $C$ genes in arsenic-resistant bacteria isolated from raw sewage and arsenic-enriched creek waters. Applied and Environmental Microbiology 68:280-288.

Silver, S. \& Phung, L.T. 2005. Genes and enzymes involved in bacterial Oxidation and reduction of inorganic arsenic. Applied and Environmental Microbiology 71:599-608.

Simeonova, D., Lievremont D., Lagarde, F., Muller, D.A., Groudeva, V.I. \& LetT, M.C. 2004. Microplate screening assay for the detection of arsenite-oxidizing and arsenatereducing bacteria. FEMS Microbiology Letters 237:24953.

Tuffin, M., De Groot, P., Deane, S. \& Rawlings, D. 2004. Multiple sets of arsenic resistance genes are present within highly arsenic-resistant industrial strains of the biomining bacterium, Acidithiobacillus caldus. International Congress Series 1275:165-172.

Wobus, A., Bleul, C., Maassen, S., Scheerer, C., Schuppler, M., JACOBS, E. \& RösKe, I. 2003. Microbial diversity and functional characterization of sediments from reservoirs of different trophic state. FEMS Microbiology Ecology 46:331-347.

Yañez, J., Fierro, V., Mansilla, H., Figueroa, L., Cornejo, L. \& BARNES, R. 2005. Arsenic speciation in human hair: a new perspective for epidemiological assessment in chronic arsenicism. Journal of Environmental Monitoring 7:13351341.

Recibido: 02.08.10

Aceptado: 02.08.11 